\title{
ANALISIS PENGAKUAN DAN PENGUKURAN PIUTANG PENDAPATAN BADAN PENDAPATAN DAERAH KOTA PALOPO
}

\author{
Perawati Ganing \\ Prodi Akuntansi, Universitas Muhammadiyah Palopo \\ perawatiganing@yahoo.com
}

\begin{abstract}
ABSTRAK
Penelitian ini bertujuan untuk mengetahui Pengakuan dan Pengukuran Piutang Pendapatan pada Badan Pendapatan Daerah (BAPENDA) Kota Palopo. Penelitian ini menggunakan metode kualitatif deskriptif yaitu dengan mendeskripsikan Akuntansi Piutang Pendapatan yang terjadi di Pemerintah Kota Palopo dengan kesesuaian pelaksanaan Peraturan Pemerintah Nomor 71 Tahun 2010 Tentang Standar Akuntansi Pemerintah sehingga dapat ditarik kesimpulan. Hasil penelitian ini menunjukkan bahwa pengakuan dan pengukuran piutang pendapatan pada Badan Pendapatan Daerah (BAPENDA) Kota Palopo telah sesuai dengan Peraturan Pemerintah Nomor 71 Tahun 2010 tentang Standar Akuntansi Pemerintah dimana Piutang Pendapatan diakui pada saat hak untuk memperoleh pendapatan telah terpenuhi dan kas atau setara kas atas pendapatan tersebut belum diterima direkening kas umum daerah sedangkan Piutang Pendapatan diukur sebesar nilai nominal piutang yang belum dilunasi. Adapun penyajian akuntansi piutang pada Pemerintah Kota Palopo telah sesuai dengan Peraturan Pemerintah Nomor 712010 tentang Standar Akuntansi Pemerintah dimana piutang yang berasal dari peraturan undang-undang disajikan di neraca sebagai Aset Lancar.
\end{abstract}

Kata Kunci: Pengakuan Piutang, Pengukuran Piutang, Penyajian Piutang, Pendapatan Daerah.

\section{ABSTRACT}

This study aims to determine the Recognition and Measurement of Receivables at the Regional Revenue Agency (BAPENDA) of Palopo City. This study uses a descriptive qualitative method that is by describing the Accounting for Receivable Income that occurs in the City of Palopo with the conformity of the implementation of Government Regulation No. 71 of 2010 concerning Government Accounting Standards so that conclusions can be drawn. The results of this study indicate that the recognition and measurement of income receivables at the Regional Revenue Agency (BAPENDA) of Palopo City are under Government Regulation Number 71 of 2010 concerning Government Accounting Standards where Revenue Receivables are recognized when the right to obtain income has been fulfilled. The regional general cash account has not yet received cash or cash equivalents on the revenue, while the Receivables are measured at the nominal value of the outstanding receivables. The presentation of accounts receivable accounting at Palopo City Government is following Government Regulation No. 712010 concerning Government Accounting Standards, where receivables originating from the laws and regulations are presented on the balance sheet as Current Assets.

Keywords: Recognition of Receivables, Measurement of Receivables, Presentation of Receivables, Regional Revenues.

\section{PENDAHULUAN}

Lembaga Pemerintah dalam menjalankan roda pemerintahannya juga mengelola keuangan Negara. Dalam Undang-Undang Nomor. 17 Tahun 2003 Tentang Keuangan Negara, khususnya pasal 1 ayat 1 dinyatakan bahwa pengertian keuangan negara adalah semua hak dan kewajiban negara yang dapat dinilai dengan uang, serta segala sesuatu baik berupa uang maupun berupa barang yang dapat dijadikan milik negara berhubung dengan pelaksanaan hak dan kewajiban tersebut . (Agus, 2012).

UU No. 17 Tahun 2003, pasal 8, salah satu ayatnya menyebutkan bahwa dalam rangka pelaksanaan kekuasaan atas pengelolaan fiskal, Menteri Keuangan mempunyai tugas sebagai melaksanakan fungsi bendahara umum negara dan menyusun laporan keuangan yang 
merupakan pertanggungjawaban pelaksanaan Anggaran Pendapatan dan Belanja Negara (APBN). Untuk melaksanakan salah satu tugas tersebut yaitu guna meningkatkan mutu pengawasan, pembinaan, dan pengelolaan keuangan Negara pemerintah menggunakan akuntansi pemerintahan.

Pemerintah berkewajiban untuk melaksanakan pengelolaan keuangan negara secara tertib, taat pada peraturan perundang- undangan, efisien, ekonomis, efektif, dan transparan, dengan memperhatikan rasa keadilan dan kepatutan. Untuk mencapai tujuan tersebut, beberapa tahun terakhir ini pemerintah mencoba untuk mencari basis akuntansi yang tepat agar dapat diterapkan dalam akuntansi pemerintahan. Sifat pemerintah yang unik, menjadikan basis akuntansi yang akan diterapkan menjadi kendala tersendiri. (Agus, 2012).

Badan Pendapatan Daerah (BAPENDA) merupakan unsur penunjang urusan Pemerintah di Bidang Keuangan yang dipimpin oleh seorang Kepala Badan yang berkedudukan di bawah dan bertanggungjawab kepada Wali Kota melalui Sekretaris Daerah. Berdasarkan Undangundang Nomor 22 Tahun 2004 yang merupakan pembaruan dari Undang-undang Nomor 25 Tahun 1999 tentang Perimbangan Keuangan antara Pemerintah Pusat - Daerah dalam rangka pelaksanaan Otonomi Daerah maka dibentuklah Badan Pendapatan Daerah.

Badan Pendapatan Daerah (BAPENDA) selaku Organisasi Perangkat Daerah (OPD) yang bertanggungjawab atas pengelolaan daerah berupaya mengelola pendapatan daerah secara optimal dan menatausahakan pendapatan tersebut dalam laporan operasional sesuai dengan Standar Akuntansi Pemerintah(SAP) yang diatur pada Peraturan Pemerintah Nomor 71 Tahun 2010 .

Standar Akuntansi Pemerintah (SAP) berlaku untuk Pemerintah Pusat dan Pemerintah Daerah dalam rangka menyusun laporan pertanggungjawaban pelaksanaan Anggaran Pendapatan dan Belanja Negara (APBN) atau Anggaran Pendapatan dan Belanja Daerah (APBD) dalam bentuk laporan keuangan. Penyusunan Anggaran Pendapatan dan Belanja Daerah tidak akan terlepas dari Standar Akuntansi Pemerintahan (SAP). Hal ini dimaksudkan untuk menyediakan suatu laporan pertanggungjawaban keuangan daerah yang akurat, dapat dipercaya, dan tepat waktu serta menciptakan pemerintah yang bersih, berwibawa dan bertanggung jawab.

Standar Akuntansi Pemerintah (SAP) menganut basis kas untuk pengakuan dan pengukuran pendapatan, serta basis akrual untuk pengakuan dan pengukuran aset, kewajiban, dan ekuitas. Basis kas digunakan untuk dapat menyusun laporan realisasi anggaran dan basis akrual 
digunakan untuk dapat menyusun neraca.

Pendapatan memiliki kaitan erat dengan akun kas, piutang, dan komponen pendapatan dalam Laporan Realisasi Anggaran (LRA) pada SAP Berbasis Kas dan SAP Akrual, maupun Laporan Operasional (LO) pada SAP Akrual. Piutang sebagai salah satu komponen dalam SAP Akrual memegang peranan dalam pengendalian internal sebagai kontrol atas realisasi pendapatan pajak daerah dalam kaitannya dengan piutang pendapatan pajak.

Pengakuan pendapatan, Saat pengakuan pendapatan pada basis akrual adalah pada saat pemerintah mempunyai hak untuk melakukan penagihan dari hasil kegiatan pemerintah. Dalam konsep basis akrual, mengenai kapan kas benar-benar diterima menjadi hal yang kurang penting. Oleh karena itu, dalam basis akrual kemudian muncul estimasi piutang tak tertagih, sebab penghasilan sudah diakui padahal kas belum diterima.

Salah satu pos yang penting di Neraca adalah piutang, dimana pada tanggal laporan keuangan, apabila terdapat hak pemerintah untuk menagih, harus dicatat sebagai penambahan aset pemerintah berupa piutang.

Peraturan Pemerintah Nomor 71 tahun 2010 tentang Standar Akuntansi Pemerintahan, yang berbasis akrual, mengatur bahwa pendapatan diakui pada saat timbulnya hak atas pendapatan tersebut atau ada aliran masuk sumber daya ekonomi dan beban diakui pada saat timbulnya kewajiban, terjadinya konsumsi aset atau terjadinya penurunan manfaat ekonomi atau potensi jasa sedangkan belanja diakui berdasarkan terjadinya pengeluaran dari rekening Kas Umum Negara/Daerah atau entitas pelaporan.

Banyak peristiwa yang menyebabkan timbulnya piutang, yang merupakan salah satu aset penambah kekayaan bersih pemerintah. Hak pemerintah ini tidak hanya terbatas pada piutang pajak dan bukan pajak, tetapi juga sumber daya ekonomi lain akibat peristiwa-peristiwa masa lalu yang menimbulkan hak pemerintah, yang akan dijabarkan lebih lanjut dalam Buletin teknis ini.

Peristiwa-peristiwa atau transaksi lain yang menimbulkan hak pemerintah untuk menagih, antara lain timbul dari perikatan misalnya transaksi pemberian pinjaman oleh pemerintah, jual beli atau pertukaran, kemitraan, dan pemberian jasa-jasa yang telah dilakukan pemerintah. Hubungan keuangan antara Pemerintah Pusat dengan pemerintah daerah, misalnya kewajiban Pemerintah Pusat dalam hubungannya dengan perimbangan keuangan, juga akan menimbulkan utang-piutang antara Pemerintah Pusat dan pemerintah daerah. Demikian pula kemungkinan timbulnya piutang akibat dari hubungan antar pemerintahan. Peristiwa lainnya 
adalah berkaitan dengan timbulnya hak tagih dalam hal terjadi kerugian negara.

Selanjutnya juga perlu diberikan pedoman terhadap pengakuan timbulnya hak tagih atas perjanjian jual beli, transaksi kemitraan, dan transaksi pemberian jasa. Selama ini dikenal pengakuan dan pencatatan piutang berdasarkan nilai nominal saja, tanpa memperhitungkan kolektibilitas sesuai dengan sifat dan karakteristik debitur. Hal tersebut akan menimbulkan moral hazard (kerugian moril bagi bangsa dan negara) yang tinggi atas akuntansi piutang, karena dapat menimbulkan adanya hak pemerintah untuk menagih, yang tidak dilaporkan atau yang disalahgunakan.

Memperhatikan kondisi akuntansi piutang yang sangat luas cakupan, macam,dan karakteristiknya, maka dirasakan perlunya Buletin Teknis tentang Piutang, untuk memberikan panduan agar terdapat kesamaan pemahaman tentang caramengindentifikasi, mengukur, dan menyajikan pos piutang, baik oleh penyusunlaporan, pengguna laporan, dan institusi yang melakukan audit atas Laporan Keuangan pemerintah.

Timbulnya piutang di lingkungan pemerintahan pada umumnya terjadi karena adanya tunggakan pungutan pendapatan dan pemberian pinjaman serta transaksi lainnya yang menimbulkan hak tagih dalam rangka pelaksanaan kegiatan pemerintahan. Pendapatan Pemerintah Pusat dikelompokkan menjadi Pendapatan Pajak, Pendapatan Negara Bukan Pajak (PNBP), dan Pendapatan Hibah. Pendapatan pemerintah daerah terdiri dari Pendapatan Asli Daerah, Pendapatan Transfer, dan Lain-lain Pendapatan Asli Daerah yang sah, dimana dalam komponen Pendapatan Asli Daerah terdapat Pendapatan Pajak Daerah dan Retribusi Daera

\section{KAJIAN PUSTAKA}

\section{Akuntansi Piutang}

Piutang merupakan salah satu pos yang penting di Neraca, dimana apabila pada tanggal laporan keuangan masih terdapat hak pemerintah untuk menagih, maka hak tagih tersebut harus dicatat sebagai penambahan aset pemerintah berupa piutang.

Piutang didefinisikan sebagai hak tagih pemerintah kepada pihak lain yang belum diterima pembayarannya. Hak tagih tersebut bisa berasal dari kewenangan pemda misalnya untuk memungut pajak daerah, retribusi daerah, atau hak tagih karena memberikan pinjaman kepada pihak lain.

\section{Pengakuan Piutang}


Piutang diakui saat timbul klaim/hak untuk menagih uang atau manfaat ekonomi lainnya kepada entitas lain. Piutang dapat diakui ketika:
a. Telah diterbitkan surat ketetapan; dan/atau
b. Telah diterbitkan surat penagihan dan telah dilaksanakan penagihan
c. Belum dilaksanakan samapai dengan periode pelaporan.

2. Pengukuran Piutang

a. Disajikan sebesar nilai yang belum dilunasi sampai tanggal pelaporan dari setiap tagihan yang ditetapkan berdasarkan surat ketetapan kurang bayar yang diterbitan; atau

b. Disajikan sebesar nilai belum dilunasi sampai dengan tanggal pelaporan dari setiap tagihan yang telah ditetapkan terutama oleh pengadilan pajak untuk wajib pajak (WP) yang mengajukan banding; atau

c. Disajikan sebesar nilai yang belum dilunasi sampai dengan tanggal pelaporan dari setiap tagihan yang masih proses banding atas keberatan dan belum ditetapkan oleh majelis tuntutan ganti rugi.

3. Pencatatan Piutang

Contoh pencatatan jurnal di buku jurnal finansial saat timbulnya hak tagih (piutang):

Tabel. 2.2

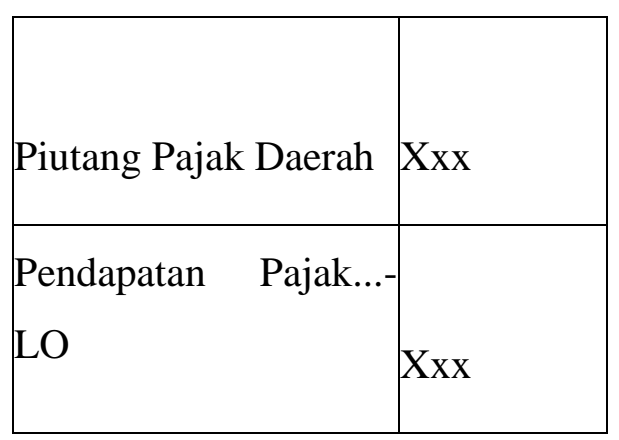

4. Bagian Lancar dan Penyisihan Piutang

Terkait pencatatan piutang, minimal terdapat 2 hal yang perlu diperhatikan pada akhir periode pelaporan oleh fungsi akuntansi di Organisasi Perangkat Daerah (OPD) maupun di Pejabat Pengelola Keuangan Daerah (PPKD), yaitu :

a. Berapa nilai dari Tagihan Pinjaman Jangka Panjang, Tagihan Penjualan 
Angsuran (TPA), dan Tuntutan Ganti Kerugian Daerah (TP/TGR) yang akan jatuh tempo dalam 12 bulan kedepan.

b. Berapa nilai penyisihan piutang Nilai dari kedua hal tersebut perlu diketahui dan dicatat dalam jurnal penyesuaian akhir periode agar tersaji nilai bagian lancar dari tagihan/piutang jangka panjang serta nilai penyisihan piutang dalam Necara. Untuk menunjang hal tersebut, dibutuhkan penatausahaan yang baik atas pengadministrasian piutang yang ada di OPD maupun PPKD. Bagian Lancar atas tagihan jangka panjang dan Penyisihan dan Penghapusan Piutang

5. Penyajian Piutang

a. Disajikan sebagai aset lancar di Neraca sebesar nilai bersih yang dapat direalisasikan (net realizable value) dan disertai dengan penyisihannya.

b. Disajikan sebagai aset lancar di Neraca sebesar nilai yang jatuh tempo dalam tahun berjalan dan yang akan ditagih dalam 12 bulan ke depan berdasarkan surat ketentuan penyelesaian yang telah ditetapkan;

c. Disajikan sebagai aset lainnya terhadap nilai yang akan dilunasi di atas 12 bulan berikutnya.

d. Aset Lancar diungkapkan pula dalam Catatan atas Laporan Keuangan.

\section{Akuntansi Pendapatan}

Peraturan Pemerintah Nomor 24 Tahun 2005 mendefinisikan pendapatan daerah meliputi semua penerimaan uang melalui rekening kas umum daerah yang menambah ekuitas dana lancar yang merupakan hak pemerintah daerah dalam 1 (satu) tahun anggaran yang tidak perlu dibayar kembali oleh daerah.

Peraturan Pemerintah Nomor 58 Tahun 2005 dan Peraturan Menteri Nomor 13 Tahun 2006 menyebutkan: "Pendapatan Daerah adalah hak pemerintah daerah yang diakui sebagai penambah nilai kekayaan bersih".

Para ahli pendapatan daerah dapat diartikan sebagai berikut: Deddi Nordiawan dan Ayuningtyas Hertianti $(2011,74)$ dalam buku Akuntansi Sektor Publik Edisi 2, Pendapatan adalah kenaikan kekayaan bersih sebagai akibat dari adanya transaksi. Bagi pemerintah, secara umum, terdapat empat sumber utama pendapatan, yaitu pajak dan kewajiban yang dipaksakan oleh pemerintah, property income yang muncul dari kepemilikan aset, penjualan 
barang dan jasa, serta sumbangan sukarela yang diterima dari unit lain.

Sehubungan dengan hal tersebut, pendapatan daerah yang dianggarkan dalam Anggaran Pendapatan dan Belanja Daerah (APBD) merupakan perkiraan yang terukur secara rasional yang dapat dicapai untuk setiap sumber pendapatan.Seluruh pendapatan daerah yang dianggarkan dalam APBD dianggarkan secara bruto, yang mempunyai makna bahwa jumlah pendapatan yang dianggarkan tidak boleh dikurangi dengan belanja yang digunakan dalam rangka menghasilkan pendapatan tersebut dan/atau dikurangi dengan bagian pemerintah pusat/daerah lain dalam rangka bagi hasil.

Definisi di atas, dapat disimpulkan bahwa pendapatan daerah adalah penerimaan uang melalui rekening kas umum daerah yang menambah ekuitas dana lancar dalam satu periode pelaporan yang terjadi dari adanya transaksi.

Sesuai amanah Peraturan Pemerintah Nomor 71 Tahun 2010, disamping pemda diwajibkan untuk menyusun laporan keuangan berbasis akrual (Laporan Operasional(LO), Neraca, Laporan Perubahan Ekuitas (LPE), dan Laporan Arus Kas (LAK)), Pemerintah Daerah (PEMDA) juga diwajibkan menyusun laporan keuangan berbasis kas (Laporan Realisasi Anggaran (LRA) dan Laporan Perubahan Saldo Anggaran Lebih (LPSAL)). Untuk itu, setiap terjadi transaksi yang menyebabkan penerimaan kas, perlu tercipta dua akun pendapatan, yaitu akun pendapatan yang akan disajikan dalam Laporan Realisasi Anggaran atau disebut dengan Pendapatan-LRA dan akun pendapatan yang akan disajikan dalam Laporan Operasional atau disebut Pendapatan-LO.

Pendapatan-LRA adalah semua penerimaan oleh Bendahara Umum Negara/Bendahara Umum Daerah atau oleh entitas pemerintah lainnya yang menambah Saldo Anggaran Lebih dalam periode tahun anggaran yang bersangkutan yang menjadi hak pemerintah, dan tidak perlu dibayar kembali oleh pemerintah. Sedangkan definisi Pendapatan-LO adalah semua hak pemerintah pusat/daerah yang diakui sebagai penambah ekuitas dalam periode tahun anggaran yang bersangkutan dan tidak perlu dibayar kembali.

a. Klasifikasi Pendapatan

Klasifikasi pendapatan menurut PP No 71 tahun 2010 dan Permendagri 64 tahun 2013 yaitu:

1) Pendapatan Asli Daerah (PAD): Pajak Daerah, Retribusi Daerah, Hasil Pengelolaan Kekayaan Daerah yang Dipisahkan, danLain-lain PAD yang Sah 
2) Pendapatan Transfer: Pendapatan Transfer Pemerintah Pusat, Pendapatan Transfer Pemerintah Lainnya, Pendapatan Transfer, Pemerintah Daerah Lainnya, danBantuan Keuangan

3) Lain-lain Pendapatan Daerah yang sah: Pendapatan Hibah, Dana Darurat, dan Pendapatan Lainnya

b. Pengakuan Pendapatan

Pengakuan Pendapatan Daerah menurut Peraturan Pemerintah Nomor 24 Tahun 2005: "Pendapatan menurut basis kas diakui pada saat diterima di Rekening Kas Umum Negara/Daerah atau oleh entitas pelaporan. Pendapatan menurut basis akrual diakui pada saat timbulnya hak atas pendapatan tersebut".

Abdul Halim (2008, 100) dalam buku Akuntansi Keuangan Daerah Edisi 3: Pendapatan yang dihitung menurut basis kas diakui pada saat diterima pada rekening kas umum daerah atau oleh entitas pelaporan. Pendapatan yang dihitung menurut basis akrual diakui pada saat timbulnya hak atas pendapatan tersebut.

Indra Bastian (2007, 147)dalam buku Sistem Akuntansi Sektor Publik Edisi 2: "Pendapatan diakui ketika kenaikan manfaat ekonomi di masa depan yang berkaitan dengan peningkatan aktiva atau penurunan kewajiban telah terjadi”.

Dari definisi di atas, dapat disimpulkan bahwa pendapatan menurut basis kas mengakui transaksi pada saat kas diterima.Pendapatan menurut basis akrual diakui pada saat terjadinya suatu transaksi, tidak semata - mata ketika kas diterima.

c. Pengukuran Pendapatan

Abdul Halim (2008, 100) dalam buku Akuntansi Keuangan Daerah Edisi 3: "Pengukuran pendapatan dilakukan menggunakan mata uang rupiah. Pendapatan yang diukur dengan mata uang asing harus dikonversi ke mata uang rupiah berdasarkan kurs tengah Bank Indonesia pada tanggal transaksi”.

Akuntansi pendapatan dilaksanakan berdasarkan azas bruto yaitu dengan membukukan penerimaan bruto, dan tidak mencatat jumlah netonya (jumlah setelah dikompensasikan dengan pengeluaran).

Transaksi pendapatan-LO dalam bentuk barang/jasa harus dilaporkan dalam Laporan Operasional dengan cara menaksir nilai wajar barang/jasa tersebut pada tanggal 
transaksi.

d. Pencatatan Pendapatan

Pencatatan Pendapatan- LRA dalam Buku Jurnal dibuat dalam konteks pemda sebagai entitas akuntansi anggaran, sedangkan pencatatan Pendapatan-LO dibuat dalam konteks pemda sebagai entitas akuntansi keuangan.

Perlu dicatat bahwa ketika ada transaksi terkait pendapatan, maka kemungkinannya adalah tunai atau kredit. Semua pendapatan selalu dicatat di buku jurnal finansial untuk menghasilkan Laporan Operasional (LO) dengan menggunakan akun Pendapatan-LO (Kode akun diawali angka "8"), sedangkan hanya yang menyangkut pendapatan tunai yang juga dicatat di buku jurnal realisasi anggaran dengan menggunakan akun Pendapatan-LRA (Kode akun diawali dengan angka “4”).

Khusus untuk akun Pendapatan-LO, disamping untuk mencatat transaksi dalam bentuk uang (Cash) baik transaksi tunai maupun kredit, juga digunakan untuk mencatat transaksi non-cash seperti hibah barang/aset.

\section{Jurnal Finansial dan Anggaran}

a. Pendapatan yang diterima akan diakui sebagai pendapatan ketika kas sudah diterima pajak, retribusi, transfer, pendapatan lain.

b. Pada akhir tahun akan dilakukan penyesuaian jika ada pajak yang belum dibayar $\square$ akan diakui sebagai piutang. Contoh :

Pada tanggal 1 Juni 20X2 diterima pendapatan pajak sebesar 300.000.000. Pada 31 Desember masih ada pajak yang belum dibayar 50.000.000

Tabel. 2.7

\begin{tabular}{|l|l|c|}
\hline \multicolumn{1}{|c|}{ Tanggal } & \multicolumn{2}{|c|}{ Finansial } \\
\hline 2 Juni 20X0 & Kas & 300.000 .000 \\
& Pendapatan-LO & 300.000 .000 \\
\hline 31 Des & Piutang Pajak & 20.000 .000 \\
\hline
\end{tabular}




\begin{tabular}{|l|l|c|}
\hline & Pendapatan-LO & 20.000 .000 \\
\hline Tanggal & Finansial & 300.000 .000 \\
\hline \multirow{3}{*}{ Juni 20X0 } & Estimasi Perubahan SAL & 300.000 .000 \\
\hline 31 Des & Pendapatan-LRA & \\
\hline
\end{tabular}

Penyajian Pendapatan

Pendapatan LRA disajikan di Laporan Realisasi Anggaran (LRA) sedangkan Pendapatan LO disajikan di Laporan Operasional (LO).

\section{METODE PENELITIAN}

Jenis penelitian yang digunakan untuk meneliti menggunakan data deskriptif yaitu dua jenis penelitian yang bertujuan untuk menjelaskan sesuatu melelui sebuah penelitian (Menurut Ulum dan Juanda (2016:78))

Sugiono (2012:13) penelitian deskriptif yaitu, penelitian yang dilakukan untuk mengetahui nilai variabel mandiri, bak satu variabel atau lebih (independen) tanpa membuat perbandingan, atau menghubungkan variabel lain.

\section{Sumber Data}

a. Data primer

Data Primer adalah data yang diperoleh atau dikumpulkan oleh peneliti secara langsung dari responden di lapangan.

b. Data Sekunder

Data Sekunder adalah data yang diperoleh atau dikumpulkan peneliti dari berbagai sumber yang ada. Data sekunder diperoleh dari berbagai sumber seperti, buku, laporan, jurnal, dan lain-lain.

\section{Teknik Pengumpulan Data}

Untuk mendapatkan data-data tersebut maka penulis akan menggunakan instrument sebagai berikut :

a. Observasi 
Penulis akan melakukan pengamatan dilokasi penelitian untukmendapatkan gambaran yang tepat mengenai subjek dan objek kajian.

b. Wawancara

Wawancara merupakan suatau cara untuk mengumpulkan data dengan cara mengajukan beberapa pertanyaan kepada subjek. Wawancara akan dilakukan secara terbuka, dan melibatkan beberapa pegawai Badan Pendapatan Daerah (BAPENDA) Kota Palopo.

\section{Teknik Analisa Data}

Analisa yang digunakan adalah analisa deskrptif yaitu mengungkapkan kejadian atau fakta, fenomena dan keadaan yang sebenarnya saat penelitian berlangsung dengan menyuguhkan apa yang sebenarnya terjadi.

Penelitian ini membandingkan data yang ada yaitu data Laporan Keuangan Pendapatan Laporan Operasional dan Laporan Keuangan Pendapatan Laporan Reaslisasi Anggaran.

\section{HASIL DAN PEMBAHASAN}

\section{Basis Akuntansi Yang Mendasari Penyusunan Laporan Keuangan}

Basis Akuntansi yang mendasari penyusunan laporan keungan yang mengacu pada Peraturan Pemerintah Nomor 71 Tahun 2010 dan Permendagri Nomor 64 tahun 2013 yakni Standar Akuntansi Pemerintah (SAP) di mana Pendapatan Realisasi Anggaran (LRA) menerapkan Basis Kas dan Pendapatan Laporan Operasional (LO) menrapkan Basis Akrual.

\section{Pengakuan Piutang Pendapatan Pada Badan Pendapatan Daerah (BAPENDA) Kota}

\section{Palopo}

Piutang Badan Pendapatan Daerah (BAPENDA) diakui pada saat hak untuk memperoleh pendapatan telah terpenuhi dan kas atau setara kas atas pendapatan tersebut belum diterima direkening kas umum daerah.

Pengakuan piutang jangka pendek dibedakan atas peristiwa yang mendasarinya. Piutang berdasarkan peraturan perundang-undangan harus didahului dengan pengakuan terhadap pendapatan yang terkait. Misalnya piutang pajak daerah oleh sebab itu pengakuan piutang pajak daerah harus dengan menendidahului dengan pangakuan terhadap pendapatan pajak daerah. Piutang dapat diakui, maka harus dipenuhi kriteria dua kriteria sebagai berikut :

a. Telah diterbitkan surat ketetapan; dan / atau

b. Telah diterbitkan surat penagihan dan telah dilaksanakan penagihan. 
Piutang berdasarkan perikatan dapat diakui sebagai piutang, apabila memenuhi kriteria sebagai berikut :

a. Harus didukung dengan naskah perjanjian yang menyatakan hak dan kewajiban secara jelas;

b. Jumlah piutang dapat diukur;

c. Telah diterbitkan surat penagihan dan telah dilaksanakan penagihan;

d. Belum dilunasi sampai dengan akhir periode pelaporan.

Pengakuan piutang Badan Pendapatan Daerah (BAPENDA) yang pembayarannya yang melampaui 12 bulan dilakukan pada saat pelaporan per tanggal neraca, dengan menentukan jangka waktu pengembaliannya sesuai dengan perikatan atau surat ketetapan piutang.

\section{Pengukuran Piutang Pendapatan}

Piutang Badan Pendapatan Daerah (BAPENDA) diukur dan dicatat sebsar nilai nominal piutang yang belum dilunasi. Pengukuran piutang yang timbul karena peraturan peundangundangan, dicatat sesuai Peraturan Wali Kota Palopo Nomor 35 Tahun 2014.

\section{Penyajian dan Pengungkapan Piutang Pendapatan}

1. Akuntansi Piutang

Ilustrasi pencatatan yang diperlukan dalam membukakan piutang yang muncul berdasarkan peraturan perundang-undangan adalah sebagai berikut :

a. Piutang pajak ditetapkan sebagaimana dituangkan dalam Surat Ketetapan Pajak Kurang Bayar (SKPKB) atau Surat Pemberitahuan Kekurangan Pembayaran Bea Masuk (SPKPBM), atau surat ketetapan yan sejenis;

Tabel 4.1

\begin{tabular}{|c|c|c|c|c|}
\hline No. & Kode Akun & Uraian & Debet & Kredit \\
\hline & & Pengakuan Piutang Pajak & & \\
\hline & $X X X$ & Piutang Pajak & $X X X$ & \\
\hline & $X X X$ & EDL Cadangan piutang & & $X X X$ \\
\hline
\end{tabular}

b. Piutang Retribusi ditetapkan berdasarkan surat tagihan terutang yang ditetapkan oleh Pemerintah Daerah Kota Palopo yang bersangkutan; 
Tabel 4.2

\begin{tabular}{|l|l|l|l|l|}
\hline No. & Kode Akun & Uraian & Debet & Kredit \\
\hline & Pengakuan Piutang Retribusi & & \\
\hline $\mathrm{XXX}$ & Piutang Retribusi & $\mathrm{XXX}$ & \\
\hline $\mathrm{XXX}$ & EDL Cadangan piutang & & $\mathrm{XXX}$ \\
\hline
\end{tabular}

Jurnal penerimaan kas atas pajak dan langsung disetor ke kas daerah di buku jurnal finansial:

Tabel 4.3

\begin{tabular}{|l|l|l|l|l|}
\hline Tgl. & Kode Akun & Uraian & Debet & Kredit \\
\hline $31 / 12 / 18$ & 3.1 .3 .01 .01 & RK PPKD & $6.000 .000,00$ & \\
\hline & 8.1 .4 .08 .15 & $\begin{array}{l}\text { Pendapatan Denda Pajak Bumi dan } \\
\text { Bangunan Perdesaan dan Perkotaan } \\
\text { LO }\end{array}$ & $6.000 .000,00$ \\
\hline
\end{tabular}

2. Penyajian Piutang di Neraca

Penyajian piutang sesuai dengan peraturan perundang- undangan merupakan tagihan yang harus dilunasi oleh para wajib pajak pada periode berjalan tahun berikutnya sehingga tidak ada piutang jenis ini melampaui satu periode berikutnyan. Piutang yang berasal dari peraturan perundang- undangan disajikan di neraca sebagai Aset Lancar, penyajiannya di neraca.

\section{NERACA}

Peraturan Pemerintah Nomor 71 Tahun 2010 tentang SAP dalam menganalisis hubungan antara akun-akun dalam neraca Pemerintah Kota Palopo tahun 2018:

Terhadap Neraca BAPENDA Kota Palopo tada beberapa hal yang dapat diperoleh melalui analisis vertikal terhadap neraca dan hubungan antar akun-akun dalam neraca.

a. Total aset sama dengan total Kewajiban di tambah Ekuitas; Yakni tahun 2017 total Rp. 
12.320.591.357,13 = Rp. 454.751.916,05 + Rp. 11.865.839.441,08. Dan untuk Tahun 2018 Total Aset Rp. 15.979.317.479,13=Rp. 1.111.301.242,05 + Rp. 14.868.298.967,08.

b. Ekuitas menunjukkan jumlah aset bersih pemerintah daerah, oleh karena itu, total ekuitas harus sama dengan selisish antara total aset dan kewajiban.

Pertumbuhan aset terlihan bahwa pada tahun 2018, terjadi pertumbuhan aset yang cukup besar jika dibanding tahun, sebelumnya, yakni sebesar Rp. 3.658.726.122,00 atau mencapai 30\% pertumbuhan ini terjadi karena adanya peningkatan pada aktiva lancar Rp. 9.742.490,00 dan kenaikan aktiva tetap sebesar Rp. 3.648.983.200,00 serta aset lainnya dari tahun 2017 tidak mengalami kenaikan dan tidak mengalami pengurangan sebesar Rp.7.500.000,00.

\section{Rekapitulasi Piutang Pajak Daerah Per 31 Desember 2017}

Analisis Rekapitulasi Piutang Pajak Daerah Badan Pendapatan Kota Palopo Tahun 2017 saldo piutang per 31 Desember 2016, yakni sebesar Rp. 3.930.935.738,33 dari mutasi tahun 2017 piutang pajak mengalami penambahan sebesar Rp. 2.137.279.562,00 dan telah mengalami pengurangan sebesar Rp. 1.247.424.039,00 sehingga saldo piutang per 31 Desember 2017 sebesar Rp. 4.820.791.261,33. Dapat kita lihat bahwa saldo piutang pajak pada tahun 2016 2017 mengalami peningkatan sebesar Rp. 889.855.523,00.

\section{Rekapitulasi Piutang Pajak Daerah Per 31 Desember 2018}

Analisis Rekapitulasi Piutang Pajak Daerah Badan Pendapatan Kota Palopo Tahun 2018 saldo piutang per 31 Desember 2017, yakni sebesar Rp. 4.820.791.261,33 dari mutasi tahun 2018 pitang pajak mengalami penambahan sebesar Rp. 2.152.887.532,00 dan telah mengalami pengurangan 1.847.932.755,00 sehingga saldo piutang pajak 2018 sebesar Rp. 5.125.746.038,33. Dapat kita lihat bahwa saldo piutang pajak pada tahun 20172018 mengalami peningkatan sebesar Rp. 304.954.777,00.

\section{Rekapitulasi Piutang Retribusi Daerah Per 31 Desember 2017}

Analisis Rekapitulasi Piutang Retribusi daerah Daerah Badan Pendapatan Kota Palopo Tahun 2017 saldo piutang per 31 Desember 2016, yakni sebesar Rp. 820.268.268,00 dari mutasi tahun 2017 piutang retribusi mengalami penambahan sebesar Rp. 346.527.000,00 dan telah mengalami pengurangan sebesar Rp. 49.532.500,000 sehingga saldo piutang per 31 Desember 2017 sebesar Rp. 1.117.262.768,00. Dapat kita lihat bahwa saldo piutang retribusi pada tahun 2016-2017 mengalami peningkatan sebesar Rp. 296.994.500,00. 
Rekapitulasi Piutang Pajak Daerah Per 31 Desember 2017

Analisis Rekapitulasi Piutang Retribusi daerah Daerah Badan Pendapatan Kota Palopo Tahun 2018 saldo piutang per 31 Desember 2017, yakni sebesar Rp. 1.117.262.768,00 dari mutasi tahun 2018 piutang retribusi mengalami penambahan sebesar Rp. 62.052.500,00 dan telah mengalami pengurangan sebesar Rp. 406.681.718,00 sehingga saldo piutang per 31 Desember 2017 sebesar Rp. 772.633.550,00. Dapat kita lihat bahwa saldo piutang retribusi pada tahun 2017 - 2018 mengalami penurunan sebesar Rp. 344.629.218,00.

Analisis Rekapitulasi Piutang Pajak Dan Retribusi Daerah, Pemerintah Kota Palopo tahun 2017-2018 dapat dilihat bahwa kondisi saldo piutang pada Badan Pendapatan Daerah (BAPENDA) total Piutang Pajak Daerah ditambah dengan total piutang retribusi daerah sehingga saldo piutang tahun 2017 sebesar Rp. 5.983.054.029,33 sedangkan tahun 2018 saldo piutang sebesar Rp. 5.898379.588,33.

\section{Pengakuan dan Pengukuran Piutang Pendapatan pada Badan Pendapatan Daerah}

Penelitian ini berusaha untuk memperoleh gambaran mengenai Analisis Pengakuan dan Pengukuran Piutang Pendapatan pada Badan Pendapatan Daerah (BAPENDA) Kota Palopo. Setelah dianalisis maka ditemukan bahwa pengakuan dan pengukuran piutang pendapatan pada Badan Pendapatan Daerah Kota Palpo telah sesuai dengan Standar Akuntansi Pemerintah (SAP) yang tertuang dalam Peraturan Pemerintah Nomor 71 Tahun 2010, temuan ini dibuktikan dengan analisis data menggunakan metode penelitian yang telah ditentukan.

Hasil penelitian ini sejalan dengan penelitian Indra Mustika Sari (2016), menunjukkan bahwa pengakuan, pengukuran, penyajian dan pengungkapan. Pendapatan-LO dilakukan ketika timbul hak dan kewajiban pemerintah daerah. Pengukuran pendapatan dilakukan dengan azas bruto. Penelitian ini juga sejalan dengan Yuri Pratiwi dan Bambang Pamungkas (2013), bahwa dimana pengakuan pendapatan menggunakan basis kas yaitu pendapatan diakui pada saat diterima pada Rekening Kas Umum Daerah. Sedangkan penelitian ini tidak sejalan yang dilakukan San Rudiyanto dan Mirza Dyah Aryanti (2018), bahawa penelitian ini tidak sesuai dengan prinsip akuntansi pendapatan sesuai dengan Standar Akuntansi Pemerintah. Penelitian ini juga tidak sejalalan dengan Betsi Karolin Korowoeyeng, Jenny Morasa, dan Dhullo Afandi (2015), menunjukkan bahwa pengakuan terhadap transaksi pendapatan atas pajak daerah, penelitian ini masih menerapkan Peraturan Pemerintah Nomor 24 Tahun 2005. 


\section{PENUTUP}

\section{KESIMPULAN}

Berdasarkan hasil wawancara dan analisis yang telah dilakukan dalam Pengakuan dan Pngukuran Piutang Pendapatan dalam Penerapan Standar Akuntansi Pemerintah pada Laporan Neraca dan Rekapitulasi Piutang Daerah Badan Pendapatan Daerah (BAPENDA) Kota Palopo Tahun 2017 dan 2018, dalam penelitian ini menemukan :

1. Laporan Neraca pada Badan Pendapatan Daerah (BAPENDA) Tahun 2017 dan 2018 secara umum telah menetapkan Peraturan Pemerintah Nomor 71 Tahun 2010 tentang Standar Akuntansi Pemerintah, hal ini didukung oleh hasil analisis data yang diperoleh.

2. Rekapitulasi Piutang Pajak Dan Retribusi Daerah Pemerintah Kota Palopo Tahun 2018 mengalami peningkatan dan efektif walaupun belum maksimal dalam pengumpulan piutang, dapat kita lihat bahwa kondisi piutang mengalami pengurangan sebesar Rp. 84.674.441,00 atau mencapai 1\%, hal ini didukung oleh hasil analisis data dan dari hasil wawancara yang diperoleh.

\section{SARAN}

Setelah mengadakan penelitian di Badan Pendapatan Daerah (BAPENDA) Kota Palopo tentang Pengakuan dan Pengukuran Piutang Pendapatan.

1. Hendaknya piutang dikendalikan dan dikelola dengan sebaik mungkin agar tingkat perputaran piutang menjadi lebih baik, sehingga presentase penagihan dapat terus meningkat dan sebaiknya mengurangi jumlah piutang yang tak tertagih.

2. Sebelum diterbitkan surat penagihan sebaiknya pihak wajib pajak diberitahu terlebih dahulu mengenai sanksi dan denda yang dikenakan apabila terjadi keterlambatan pembayaran surat penagihan dengan tanggal jatuh tempo yang telah ditentukan.

3. Saran untuk peneliti selanjutnya di harapkan untuk lebih memperhatikan indikatorindikator lain yang belum di cantumkan oleh penulis dalam penelitian ini.

\section{DAFTAR PUSTAKA}

Abdul Halim. 2011. Analisis Investasi. Edisi kedua. Jakarta: Salemba Empat.

Amrie Firmasyah, Marmah Hadi. 2015. Modul Kerjasama Peningkatan Kapasitas Pengelolaan Keuangan Daerah. Jakarta. 
Betsi Karolin Korowocyeng, Jenny Morasa, dan Dhullo Afandi. 2015. Analisis Perlakukan Akuntansi Pajak Daerah Di Kota Tomohon. Jurnal Berkala Ilmiah Efisiensi Volume 15 No. 05 Tahun 2015.

Bastian, Indra. 2007. Sistem Akuntansi Sektor Publik. Edisi 2, Salemba Empat. Jakarta.

Halim, Abdul.2008. Akuntansi Keuangan Daerah. Edisi 3, Salemba Empat, Jakarta.

Halim, Abdul.2008. Akuntansi Keuangan Daerah. Edisi 3, Salemba Empat, Jakarta.

Hariyanto, Agus. 2012. Penggunaan Basis Akrual Dalam Akuntansi Pemerintahan Di Indonesia. Dharma Ekonomi. No. 36 / Th. XIX / Oktober 2012.

Indra Mustika Sari. 2016. Perlakuan Akuntansi Pendapatan-LO dan Beban pada Pemerintah Kabupaten Kediri Berdasarkan Standar Akuntansi Pemerintahan (SAP) Peraturan Pemerintah Nomor 71 Tahun 2010. Skripsi, Malang: Jurusan Akuntansi Fakultas Ekonomi, Universitas Islam Negeri (UIN).

Natalia Rawung. 2016. Analisis Pendapatan Asli Daerah Dan Pencatatannya Pada Dinas Pendapatan Kota Manado. Jurnal EMBA Vol.4 No.1 Maret 2016, Hal. 496-502

Nordiawan, Dedi dan Ayuningtyas Hertianty. 2011. Akuntansi Sektor Publik. Edisi 2, Salemba, Jakarta. Peraturan Menteri Dalam Negeri Nommor 13 Tahun 2006 tentang Pedoman Pengelolaan Keuangan Daerah

Peraturan Menteri Dalam Negeri Nomor 59 Tahun 2007 tentang Perubahan Atas. Peraturan Menteri Dalam Negeri Nomor 64 Tahun 2013 tentang Penerapan Standar. Peraturan Pemerintah Nomor 24 Tahun 2005 tentang Standar Akuntansi Pemerintah. Peraturan Pemerintah Nomor 71 Tahun 2010 tentang Standar Akuntansi Pemerintah.

Republik Indonesia. 2005. Peraturan Pemerintah No 58 Tahun 2005 tentang Pengelolaan Keuangan Daerah. Jakarta: Legalitas.

Republik Indonesia. 2006. Permendagri No 13 Tahun 2006 tentang Pedoman Pengelolaan Keuangan Daerah. Jakarta: Legalitas.

San Rudiyanto dan Mirza Dyah Ariyanti. 2018. Analisis Implementasi Kebijakan Akuntansi Pendapatan pada Pemerintah Kota Malang. Malang.

Yuri Pratiwi, Bambang Pamungkas. 2013. Analisis Pengakuan Pendapatan, Belanja, Dan Pembiayaan Daerah Pada Pemerintah Daerah Kota Bogor. Jurnal Ilmiah Akuntansi Kesatuan Vol. 2 No. 1, 2014 pg. 59 - 72 STIE Kesatuan ISSN 2337 7852

2003, Undang-Undang Nomor 17 Tahun 2003 Tentang Keuangan Negara. 